\title{
Osteocalcin, growth, and inhaled corticosteroids: a prospective study
}

Iolo Doull, Nicholas Freezer, Stephen Holgate

\begin{abstract}
Objectives-To determine the relationship between biochemical markers of bone metabolism and statural growth, and their suitability as surrogate markers of inhaled corticosteroid induced growth suppression.

Design-Randomised, double blind, placebo controlled comparison of inhaled beclomethasone dipropionate $200 \mu \mathrm{g}$ twice daily as dry powder for six months.

Setting-Southampton.

Outcome measures-Serum osteocalcin, urinary deoxypyridinoline, and statural growth.

Subjects -7 to 9 year old children with recurrent wheeze.

Results-There were no significant differences in serum osteocalcin between the beclomethasone dipropionate and placebo group measured at baseline or after three and six months' treatment, while deoxypyridinoline was significantly higher in the placebo treated children after three months. Growth was significantly decreased in the beclomethasone dipropionate group over the course of the study. Growth over the six months, both in those receiving beclomethasone dipropionate and those receiving placebo, was significantly correlated with serum osteocalcin measured at three months and six months.

Conclusion-Although serum osteocalcin shows excellent correlation with growth, it is a poor marker for decreased growth associated with use of inhaled corticosteroids.

(Arch Dis Child 1996;74:497-501)
\end{abstract}

Keywords: osteocalcin, growth, inhaled coticosteroids.

Systemic corticosteroids are an effective treatment of asthma, but in childhood result in impaired statural growth ${ }^{1}$ and in adults in trabecular bone mineral loss of up to $7 \%$ per year, ${ }^{2}$ with an increased risk of fractures. ${ }^{3}$ Inhaled corticosteroids have fewer side effects than oral corticosteroids, but may nevertheless impair growth in childhood ${ }^{4}$ and in adults adversely affect bone turnover manifest as decreased serum osteocalcin concentrations. ${ }^{5-11}$

Osteocalcin is the most abundant noncollagenous protein found in bone accounting for $1-2 \%$ of the total protein. It is a 49 amino acid residue peptide, two or three of which are the vitamin $\mathrm{K}$ dependent amino acid, carboxyglutamic acid. It is almost exclusively synthe- sised by osteoblasts and is incorporated into the bone matrix and dentine where it binds to hydroxyapatite. ${ }^{12} \mathrm{~A}$ small amount of the newly formed osteocalcin is released into the circulation, and as it is not normally released during the resorption of bone protein, it is therefore a specific marker for osteoblastic activity. Cross sectional studies have shown that serum osteocalcin concentrations in childhood parallel growth velocity. ${ }^{13-16}$

Deoxypyridinoline is found mainly in type I collagen of bone, and is a marker of collagen breakdown. It is formed during the posttranslational extracellular maturation of fibrillar collagen, and is released in to the circulation as bone is resorbed, being excreted via the kidneys. Unlike hydroxyproline, deoxypyridinoline is neither metabolised in the body nor influenced by dietary intake of collagen. In adults deoxypyridinoline excretion shows good correlation with radioisotopic ${ }^{17}$ and histomorphometric ${ }^{18}$ assessment of bone turnover.

The aim of this study was to prospectively establish the relationship between biochemical markers of bone metabolism and statural growth, and if inhaled corticosteroids did adversely affected growth or bone metabolism, to establish whether biochemical indices of bone metabolism might act as surrogate markers for growth suppression.

\section{Methods}

SUBJECTS

The subjects took part in a community based study to assess the effect of inhaled beclomethasone dipropionate administered as dry powder on wheezing episodes in schoolchildren as previously described. ${ }^{19}$ Children suitable for the longitudinal study were selected on the basis of either five or more wheezing episodes in the preceding year or an episode of wheezing lasting for three days or more in the preceding year. Exclusion criteria included the use of inhaled or oral corticosteroids, or coexistent respiratory disease such as cystic fibrosis. Altogether 104 children fulfilled the enrolment criteria and agreed to enter the study.

Before treatment randomisation the children were asked to give a sample of blood and collect an overnight sample of urine. Blood was taken using topical anaesthetic (EMLA, Astra Pharmaceuticals), centrifuged and the serum stored at $-20^{\circ} \mathrm{C}$ within three hours of collection. Blood samples were always collected after school, usually at the exact same time of day for each child. A timed overnight urine sample was collected on the same day. Urine volumes were 
measured and aliquots stored at $-20^{\circ} \mathrm{C}$, samples being frozen within six hours of voiding.

After collection of the baseline samples, the children were randomised to receive either beclomethasone dipropionate $200 \mu \mathrm{g}$ twice daily or placebo as dry powder via a Diskhaler (Allen and Hanburys). Further paired blood and urine samples were collected after three and six months' treatment. As willingness to supply blood and urine samples was not a prerequisite for entry, the number of blood and urine samples varied over the course of the study.

\section{MEASUREMENT OF GROWTH}

The children were assessed every two to four weeks and their height recorded as previously described. ${ }^{19}$ At each visit the child's height was measured by a single observer (ID) using a Raven Minimeter (Raven Equipment Ltd). The Minimeter is portable, and as accurate as a fixed stadiometer. ${ }^{20}$ The standard deviation of a single height measurement calculated as per Voss et $a l^{20}$ was $0.10 \mathrm{~cm}$. The child was measured barefoot with the Minimeter being positioned on the child's head 'blindly' before being read. Three measurements were taken in this manner with no reference to the previous measurements, and the mean calculated. If one measurement was very discrepant the entire procedure was repeated. Weight was measured using Seca scales. The pubertal stage of the children was assessed at the end of the study. Compliance with treatment was assessed by counting the used Diskhaler blisters.

BIOCHEMICAL MEASUREMENTS

All measurements were performed in duplicate. Osteocalcin was measured by radioimmunoassay (Diagnostic Systems Laboratories) using antiserum raised in rabbits to bovine osteocalcin and free ${ }^{125} \mathrm{I}$ labelled osteocalcin. ${ }^{21}$ Urinary deoxypyridinoline was measured by competitive immunoassay (Metra Biosystems) using a monoclonal antibody to deoxypyridinoline. Urinary creatinine was measured by standard automated methods. ${ }^{22}$ Overnight urinary deoxypyridinoline excretion was expressed as deoxypyridinoline/creatinine ratio. Interassay coefficient of variation was $11.2 \%$ for osteocalcin and $\mathbf{1 0 . 3 \%}$ for deoxypyridinoline.

Permission for the study was obtained from the ethics committee of the Southampton University Teaching Hospitals. The children gave informed assent and the parents informed written consent.

\section{DATA ANALYSES}

Statistical analysis was performed using SPSSPC. Growth over the study was calculated by linear regression of the multiple height measurements on treatment for each child, and expressed as $\mathrm{mm}$ /week. Urinary deoxypyridinoline /creatinine ratio was log transformed to normalise the distribution. Comparison of use of concomitant medication used the $\chi^{2}$ test. Paired Student's $t$ test was used for changes within the whole group over time, and
Table 1 Regular concomitant medication taken by children in the beclomethasone dipropionate and placebo groups

\begin{tabular}{lll}
\hline Regular medication & $\begin{array}{l}\text { Beclomethasone } \\
\text { dipropionate }\end{array}$ & Placebo \\
\hline Sodium cromoglycate & 4 & 4 \\
$\begin{array}{l}\text { Nasal beclomethasone } \\
\text { dipropionate }\end{array}$ & 0 & \\
Theophylline & 1 & 0 \\
Topical corticosteroids for eczema & 3 & 3 \\
Terfenadine & 1 & 2 \\
\hline
\end{tabular}

unpaired Student's $t$ test to compare differences between the two groups at different time points. Association between continuous variables was analysed by correlation and multiple linear regression. Results are presented as means and the $95 \%$ confidence interval of the difference (95\%CI diff), and for the log transformed data ratio of means and $95 \%$ CI diff of the ratio of means.

\section{Results}

Of the 104 children who entered the study 52 received inhaled beclomethasone dipropionate ( 37 boys, 15 girls) and 52 placebo ( 36 boys, 16 girls). Ninety four children completed the study of whom 50 received beclomethasone dipropionate and 44 placebo. Before randomisation there were no significant differences between the beclomethasone dipropionate and placebo treated groups in mean age at entry in to the study ( 100.3 months $v 99.4$ months, range $86-119 v 86-119)$ or in height SD scores (mean $0.53 v 0.33, \mathrm{p}=0.27$ ). Ten children were removed from the analysis due to confounding factors: six children were entering puberty, three had been started on regular inhaled corticosteroids by their general practitioners, and one child had injured his back affecting his growth. Seventeen children were receiving concomitant medication (see table 1). There were no significant differences in concomitant medication between the two groups. In addition two children receiving beclomethasone dipropionate and three receiving placebo were given oral corticosteroids by their general practitioner during the study. Mean compliance with treatment was similar in the two groups: $75.2 \%$ in the beclomethasone dipropionate treated group compared with $75.9 \%$ in the placebo group (95\%CI diff -8.15 to 9.55$)$.

\section{OSTEOCALCIN}

Mean serum osteocalcin in the beclomethasone dipropionate and placebo groups over the six months are shown in fig 1 . There was no significant difference in serum osteocalcin between the beclomethasone dipropionate and placebo groups at baseline or at either of the two measurements while on treatment, and thus for further analysis the two groups are combined. Mean (SD) serum osteocalcin for all the children decreased from 20.3 (4.90) $\mathrm{ng} / \mathrm{ml}$ at baseline to 19.1 (4.66) after three months and 16.5 (4.81) $\mathrm{ng} / \mathrm{ml}$ after six months, with a significant decrease between three months and six months $(95 \% \mathrm{CI}$ diff 0.96 
to $5.3, p=0.006)$. There was no significant difference in serum osteocalcin between girls and boys at any of the three time points.

URINARY DEOXYPYRIDINOLINE/CREATININE RATIO Geometric mean urinary deoxypyridinoline/ creatinine ratio in the beclomethasone dipropionate and placebo groups over the six months are shown in fig 2 . There were no significant differences in urinary deoxypyridinoline concentrations between the beclomethasone dipropionate and placebo treated group at baseline $(20.2 v 18.4 \mathrm{nmol} / \mathrm{mmol}$ creatinine, ratio $0.911,95 \%$ CI 0.75 to 2.95 ) or at six months $(16.5 v 18.0 \mathrm{nmol} / \mathrm{mmol}$ creatinine, ratio $1.19,95 \%$ CI 0.94 to 1.51 ), but urinary deoxypyridinoline was significantly higher in the placebo treated group compared with the beclomethasone dipropionate treated group after three months $(17.6 v 22.64 \mathrm{nmol} / \mathrm{mmol}$ creatinine, ratio $1.29,95 \%$ CI 1.01 to 1.65 ). Geometric mean (SD) urinary deoxypyridinoline for the children as a whole decreased over the course of the study from $19.4(1.58) \mathrm{nmol} /$ mmol creatinine at baseline to 19.8 (1.66) $\mathrm{nmol} / \mathrm{mmol}$ creatinine after three months and $16.4(1.55) \mathrm{nmol} / \mathrm{mmol}$ creatinine after six months, with a significant decrease from three months to six months (ratio $1.35,95 \%$ CI 1.15 to $1.6, \mathrm{p}=0.01)$. There was no significant difference in urinary deoxypyridinoline/ creatinine between girls and boys at any of the three time points.

GROWTH

There was no significant difference in height at baseline between the beclomethasone dipropi-

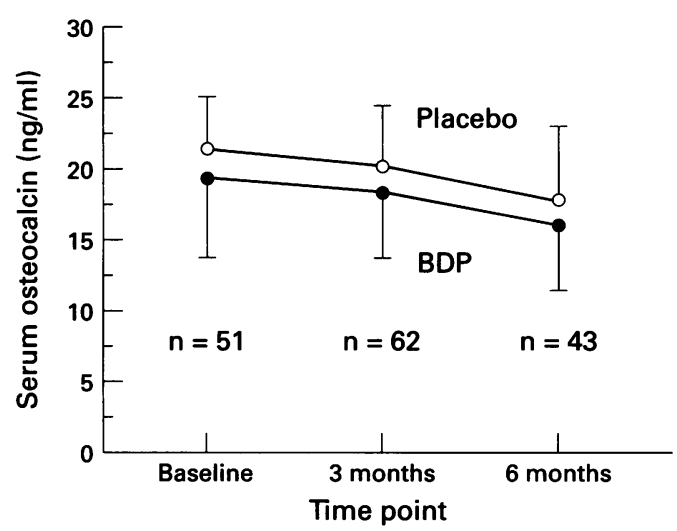

Figure 1 Mean(SD) of serum osteocalcin over six months.

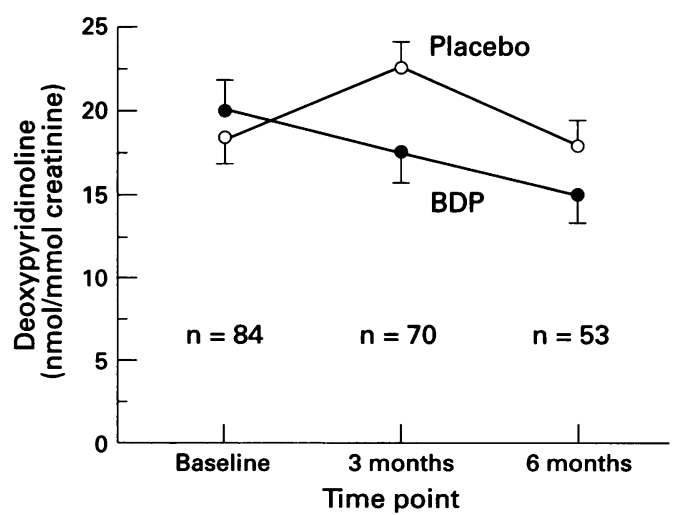

Figure 2 Mean(SD) of urinary deoxypyridinoline over six months. onate and placebo treated groups (130.1 v $128.4 \mathrm{~cm}, \mathrm{p}=0.216$ ). As previously reported, ${ }^{19}$ the mean growth was significantly decreased in the beclomethasone dipropionate treated group compared with placebo $(0.79 v 1.14$ $\mathrm{mm} /$ week, $95 \%$ CI diff 0.25 to 0.46 , $\mathrm{p}<0.0001$ ).

Mean growth over the six months of the study was significantly correlated with serum osteocalcin measured at three (fig 3) and six months (fig 4), both in those children receiving beclomethasone dipropionate and in those children receiving placebo $(r=0.44, \mathrm{p}=0.01$ and $r=0.57, \mathrm{p}=0.005$ respectively at three months; and $r=0.5, \mathrm{p}=0.01$ and $r=0.52$, $\mathrm{p}=0.05$ respectively at six months), but was unrelated to serum osteocalcin measured at baseline ( $r=0.1, \mathrm{p}=0.6$ and $r=0.05, \mathrm{p}=0.8$ ).

Mean growth over the six months was significantly correlated with urinary deoxypyridinoline/creatinine ratio at three months in only the beclomethasone dipropionate treated group $(r=0.4, p=0.02)$, but was unrelated to any other measurements.

\section{Discussion}

Over a six month period, compared with placebo, regular inhaled beclomethasone dipropionate $200 \mu \mathrm{g}$ twice daily had no significant effect on either serum osteocalcin, a marker of bone formation, nor urinary deoxypyridinoline, a marker of bone resorption. Of

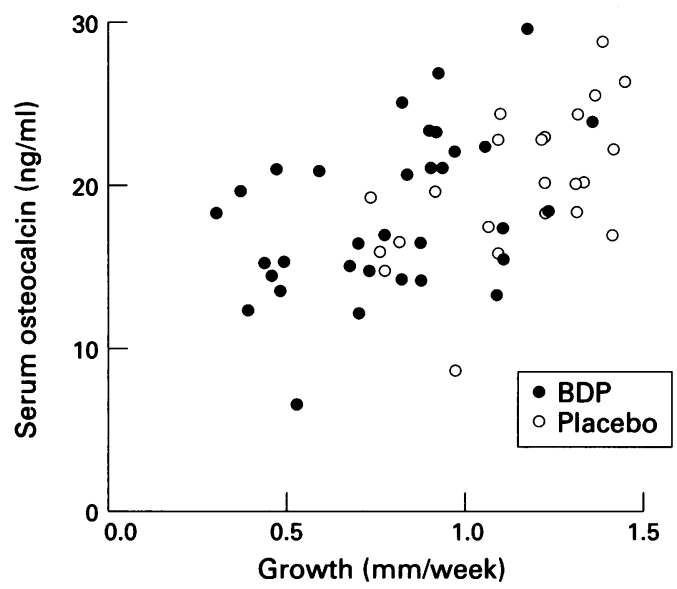

Figure 3 Serum osteocalcin measured at three months and growth by treatment.

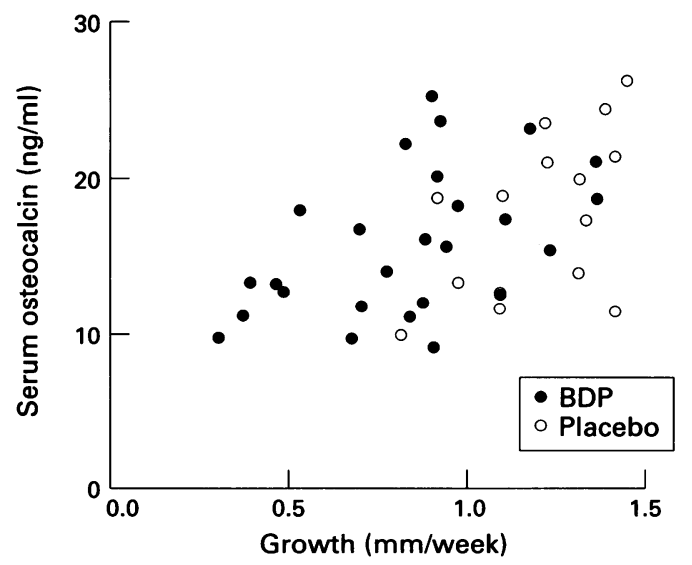

Figure 4 Serum osteocalcin measured at six months and growth by treatment. 
note was that serum osteocalcin measured after three and six months was significantly related to statural growth over the six month period.

These findings may at first appear at odds with our previously reported finding in this group of children of decreased growth in those receiving beclomethasone dipropionate. ${ }^{19} \mathrm{Al}$ though serum osteocalcin showed significant correlation with growth over the six month period, and we have previously demonstrated decreased growth in those children randomised to receive beclomethasone dipropionate, beclomethasone dipropionate did not have any discernible effect on serum osteocalcin. However as the correlation between growth and serum osteocalcin was 0.5 , only $25 \%$ of the variation in growth would be dependent on the serum osteocalcin. Three other possibilities warrant consideration. Firstly it may be that beclomethasone dipropionate at a dose of $200 \mu \mathrm{g}$ twice a day has little effect on bone turnover in children, and although it clearly has an affect on growth, this is not mediated through an effect on bone. Secondly beclomethasone dipropionate may have an effect on bone turnover that results in decreased growth, but that neither serum osteocalcin nor urinary deoxypyridinoline are sufficiently sensitive to detect this effect. A third possibility is that beclomethasone dipropionate's effect on bone turnover is short term, and that bone turnover had returned to normal by the time we measured it after three months' treatment. We feel that the first possibility is the most likely. Osteocalcin has been demonstrated to be a sensitive measure of the effect of low dose prednisolone in childhood, ${ }^{23}$ and our findings clearly demonstrate osteocalcin's relationship to growth.

Cross sectional studies where serum osteocalcin has been measured report broadly similar findings with serum osteocalcin concentrations in childhood paralleling growth velocity. ${ }^{13-16}$ The only prospective study to date of growth and serum osteocalcin reported no significant relationship between growth in the first 9 months of age and serum osteocalcin measured at 2, 6, and 9 months of age. ${ }^{24}$ In this age group serum osteocalcin might however reflect vitamin $\mathrm{K}$ status rather than osteoblastic activity. Serum osteocalcin has been proposed as a predictive marker of response to treatment in children being started on growth hormone replacement treatment, although the published evidence is conflicting. ${ }^{16}$ To our knowledge ours is the first prospective study demonstrating a significant relationship between serum osteocalcin and growth in normal children.

Both serum osteocalcin and urinary deoxypyridinoline for the group of children as a whole decreased over the course of the study. Furthermore growth over the six months of our study was significantly related to serum osteocalcin measured at the three month midpoint and after six months, but was unrelated to the baseline measurement. Both statural growth ${ }^{25}$ and serum osteocalcin ${ }^{26}$ demonstrate seasonal variation, with both growth and osteocalcin being higher in the summer. It may be that the initial baseline sample reflected growth over the preceding summer. It is interesting that the urinary deoxypyridinoline increased after three months in the placebo treated group, the opposite of what would have been expected if the beclomethasone dipropionate had a significant effect on bone turnover. We are unable to explain this finding, and it may be a statistical artefact.

Most of the information on the effects of corticosteroids on biochemical markers of bone turnover in asthmatics has been obtained in adults. In non-asthmatic adult volunteers a mean daily dose of beclomethasone dipropionate $400 \mu \mathrm{g}$ to $2000 \mu \mathrm{g} /$ day or budesonide 800-3200 $\mu \mathrm{g} /$ day significantly decreased serum osteocalcin within one week. ${ }^{5-11}$ In a prospective study of newly diagnosed asthmatics started on beclomethasone dipropionate increasing from 400 to $2000 \mu \mathrm{g} /$ day, serum osteocalcin significantly decreased by nine weeks. $^{9}$

There is a paucity of data on the effect of corticosteroids on bone turnover in asthmatic children. König et al related bone markers and bone mineral content in three groups of children: a group of children receiving inhaled corticosteroids, a group of control asthmatic children not requiring inhaled corticosteroids, and a group of normal children. ${ }^{27}$ They concluded that beclomethasone dipropionate up to $800 \mu \mathrm{g} /$ day did not reduce bone mineralisation or increase resorption. Of note however was that both groups of asthmatic children had significantly lower serum osteocalcin concentrations than the normal controls, suggesting that asthma per se can reduce osteocalcin independent of the effect of corticosteroids. Wolthers et al described the short term (two week) effect of oral prednisolone and inhaled budesonide in prepubertal asthmatic children. ${ }^{23}$ Oral prednisolone $2.5 \mathrm{mg}$ and $5 \mathrm{mg} /$ day demonstrated a dose related reduction in serum osteocalcin, but budesonide at a dose of $800 \mu \mathrm{g} /$ day caused no significant effect. Similarly in an open follow up of 23 children started on either sodium cromoglycate or inhaled budesonide $400 \mu \mathrm{g} / \mathrm{m}^{2}$ per day, Sorva $e t$ al reported no significant change in serum osteocalcin. ${ }^{28}$

Thus the limited reports on the effect of corticosteroids on bone turnover in asthmatic children suggest that oral steroids have a significant effect on biochemical markers of osteoblastic function and bone resorption, but that inhaled corticosteroids up to a dose of 800 $\mu \mathrm{g} /$ day have little effect on biochemical markers or bone mineralisation. Our findings are in accordance with these conclusions, but further suggest that biochemical indices of bone turnover are poor markers for the growth suppressive actions of inhaled corticosteroids.

We would like to thank The Wessex Medical Trust and Allen and Hanbury (UK) and for financial support, and Allen and Hanbury (UK) for providing the dry powder medication. We would also thank Ms S Smith and Ms J Schreiber for organisational assistance, Ms F Lampe for statistical advice, Dr P Wood and $\mathrm{Mr} \mathrm{S}$ Donovan for measuring the osteocalcin and deoxypyridinoline, and Ms $M$ White and Dr D Rowe for the creatinine. 
1 Spock A. Growth patterns in 200 children with bronchial asthma. Ann Allergy 1965; 23: 608-15.

2 Ruegsegger P, Medici TC, Anliker M. Corticosteroid induced bone loss. A longitudinal study of alternate day therapy in patients with bronchial asthma using quantitative computed tomography. Eur f Clin Pharmacol 1983; 25 : tive com

3 Adinoff $\mathrm{AD}$, Hollister JR. Steroid induced fractures and bone loss in patients with asthma. N Engl F Med 1983; 309: 265-8.

4 Littlewood JM, Johnson AW, Edwards PA, Littlewood AE. Growth retardation in asthmatic children treated with inhaled beclomethasone dipropionate. Lancet 1988; i: 116-7.

5 Jennings BH, Andersson KE, Johansson SA. Assessment of systemic effects of inhaled glucocorticosteroids: comparison of the effects of inhaled budesonide and oral prednisolone on adrenal function and markers of bone turnover. Eur $f$ Clin Pharmacol 1991; 40: 77-82.

6 Pouw EM, Prummel MF, Oosting H, Roos CM, Endert E. Beclomethasone inhalation decreases serum osteocalcin concentrations. BMF 1991; 302: 627-8.

7 Teelucksingh S, Padfield PL, Tibi L, Gough KJ, Holt PR. Inhaled corticosteroids, bone formation, and osteocalcin Lancet 1991; 338: 60-1.

8 Meeran K, Hattersley A, Burrin J,Shiner R, Ibbertson K. Oral and inhaled corticosteroids suppress bone formation. Am Rev Respir Dis 1991; 143(4,pt2):abst 625

9 Puolijoki H, Liippo K, Herrala J, Salmi J, Risteli J, Tala E. Does high dose inhaled beclomethasone (BDP) effect the calcium metabolism. Eur Respir ₹ 1991; 4(suppl 14):483s.

10 Toogood JH, Jennings B, Hodsman AB, Baskerville J, Fraher LJ. Effects of dose and dosing schedule of inhaled budesonide on bone turnover. $f$ Allergy Clin Immunol 1991; 88: 572-80.

11 Hodsman AB, Toogood JH, Jennings B, Fraher LJ, Baskerville JC. Differential effects of inhaled budesonide and oral prednisolone on serum osteocalcin. $\mathcal{f}$ Clin Endocrinol Mrednisolone on serum $1991 ; 72: 530-40$.

12 Price PA, Otsuka AS, Poser JW, Kristaponis J, Raman N. Characterization of a carboxyglutamic acid containing protein from bone. Biochemistry 1976; 73: 1447-51.

13 Cole DEC, Carpenter DO, Gundberg CM. Serum osteocalcin concentrations in children with metabolic bone disease. F Pediatr 1985; 106: 770-6.

14 Delmas PD, Chatelain P, Malaval L, Bonne G. Serum bone GLA-protein in growth hormone deficient children. $\mathcal{f}$ Bone Miner Res 1986; 1: 333-8.

15 Johansen JS, Jensen SB, Riis BJ, Ramussen L, Zachman M, Christiansen C. Serum bone GLA protein: a potential marker of growth hormone (GH) deficiency and the response to GH therapy. $\mathcal{F}$ Clin Endocrinol Metab 1990; 71: 122-6.

16 Kanzaki S, Hosoda K, Moriwake T, et al. Serum propeptide and intact molecular osteocalcin in normal children and children with growth hormone (GH) deficiency: a children with growth hormone (GH) deficiency: a potential marker of bone growth and response to

17 Eastell R, Hampton L, Colwell A, Green JR, Assiri AM, Hemp R. Urinary crosslinks are highly correlated with radioisotopic measurements one resorption. In: Christiansen C, Overgaard K, eds. Osteoporosis 1990. Osteopress, 1990:469-70.

18 Delmas PD, Schlemmer A, Gineyts E, Riis B, Christioansen C. Urinary excretion of pyridinoline crosslinks correlates with bone turnover measured on iliac crest biopsy in patients with vertebral osteoporosis. $f$ Bone Miner Res 1991; 6: 639-44.

19 Doull IJM, Freezer NJ, Holgate ST. Growth of prepubertal children with mild asthma treated with inhaled beclomethasone dipropionate. Am $₹$ Respir Crit Care Med 1995; 151: $1715-9$.

20 Voss LD, Bailey BJR, Cumming K, Wilkin TJ, Betts PR. The reliability of height measurement (the Wessex growth study). Arch Dis Child 1990; 65: 1340-4.

21 Delmas PD. Biochemical markers of bone turnover: methodology and clinical use in osteoporosis. $\mathrm{Am} \mathcal{F} \mathrm{Med}$ 1991; 91(suppl 5B):59S-63S.

22 Rossignol B, Rossignol D, Petitclerc C. Improvement of creatinine measurement on RA-1000. Clin Biochem 1984; 17: 203-4 (abst).

23 Wolthers OD, Riis BJ, Pedersen S. Bone turnover in asthmatic children treated with oral prednisolone or inhaled budesonide. Pediatr Pulmonol 1993; 16: 341-6.

24 Michaelsen KF, Johansen JS, Samuelson G, Price PA, Christiansen C. Serum bone $\gamma$ carboxyglutamic acid protein in a longitudinal study in infants: lower values in protein in a longitudinal study in infants: lower
formula fed infants. Pediatr Res 1992; 31: 410-5.

25 Tanner JM. A history of the study of human growth. Cambridge: Cambridge University Press, 1981

26 Thomsen K, Eriksen EF, Jorgsen JCR, Charles P, Mosekilde L. Seasonal variation of bone GLA protein. Scand $\mathcal{f}$ Clin Invest 1989; 49: 605-11.

27 König P, Hillman L, Cervantes C, et al. Bone metabolism in children with asthma treated with inhaled beclomethasone dipropionate. F Pediatr 1993; 122: 219-26.

28 Sorva R, Turpeinen M, Juntunen-Backman $\mathrm{K}$, Karonen SL, Sorva A. Effects of inhaled budesonide on serum markers of bone metabolism in children with asthma. $\mathcal{f}$ Allergy Clin Immunol 1992; 90: 808-15. 